\title{
PERAN PEMERINTAH DALAM PENGELOLAAN \\ PROGRAM CSR DI KABUPATEN TRENGGALEK \\ (Studi Implementasi Peraturan Daerah Provinsi Jawa Timur Nomor 4 Tahun 2011 Tentang \\ Tanggungjawab Sosial Perusahaan)
}

\author{
The Role Of Government In Managing \\ CSR Program In Trenggalek Regency \\ (Study Of Implementation Of East Java Province Regional Regulation Number 4 Of 2011 \\ Concerning Corporate Social Responsibility)
}

$\operatorname{Reban}^{1}$ \& Imam Fachruddin ${ }^{2}$

1,2Magister Ilmu Administrasi Universitas Kadiri

\begin{abstract}
Abstrak
Pelaksanaan Corporate Social Responsibility (CSR) Program atau Program Tanggungjawab Sosial Perusahaan di Kabupaten Trenggalek telah diatur dalam Peraturan Daerah Nomor 3 Tahun 2016 Tentang Tanggungjawab sosial Perusahaan. Salah satu yang menjadi alasan dari pelaksanaan program ini adalah karena keterbatasan dana atau pembiayaan pemerintah dalam pembangunan oleh karena itu perlu perhatian, dukungan dan kerjasama dari dunia usaha untuk turut serta dan bertanggung jawab terhadap pembangunan di lingkungan sekitarnya. Tujuan dari penelitian ini adalah untuk mengetahui peran Pemerintah Kabupaten Trenggalek dalam pengelolaan pelaksanaan Program CSR dan manfaat dari Program CSR terhadap pembangunan di Kabupaten Trenggalek. Sumber data/ Informan dalam penelitian ini yaitu Tim Fasilitasi Pengelolaan Program CSR. Penelitian ini menggunakan Metode Analisis Data Kualitatif. Hasilnya menunjukkan bahwa Pemerintah mempunyai peran yang sangat stategis dalam pengelolaan pelaksanaan Program CSR yaitu pemerintah sebagai penyedia data/ informasi, sebagai perencana dan sebagai pelaksana monitoring dan evaluasi terhadap pelaksanaan program CSR. Sedangkan manfaat dari pelaksanaan Program CSR yaitu sudah dirasakan dan dinikmati oleh masyarakat dengan tersedianya sarana prasarana, fasilitas umum sampai untuk keperluan sehari-hari maupun pendidikan.
\end{abstract}

Kata Kunci: Peran pemerintah; CSR; Manajemen CSR

\begin{abstract}
The realization of the Corporate Social Responsibility Program (CSR) of industry in Trenggalek regency has been arranged in District Regulation Number 3, 2016 It is about corporate social responsibility. A reason for the realization of this program is fund limitation or government funding in development, so it needs attention, motivation and cooperation from corporate to participate and be responsible towards the development. In the environment. This research aims to know the government's role in Trenggalek regency in case of management for the realization of the CSR program and the advantage of this program forward Trenggalek regency development. Data resources or informants in this research are management facilitate the team of the CSR program. This research used a Qualitative data analysis method. The results of this research show that the government has a very strategic role in the management of the realization of the CSR program, that is the government as the data/ information provider, planner and the manager of monitoring and evaluation forward the realization of the CSR Program. The advantage of the achievement of the CSR Program has been enjoyed by Society, like public facilities for daily life or education.
\end{abstract}

Keywords: Government role; CSR; CSR management

\section{A. PENDAHULUAN}

RPJMD Kabupaten Trenggalek Tahun 2016-2021 merupakan penjabaran Visi Bupati dan Wakil Bupati, yaitu : "Mewujudkan Kabupaten Trenggalek yang Maju, Adil, Sejahtera, serta Berkepribadian berdasarkan Iman dan Takwa".
Untuk mewujudkan Visi, Misi Kepala Daerah dan Tema Pemerintah Daerah Tahun 2016 yang dituangkan dalam berbagai Program dan Kegiatan maka dibutuhkan peran aktif dan partisipasi dari seluruh masyarakat dan stakeholders. Selain itu oleh karena kemampuan 
pemerintah dalam pembiayaan pembangunan yang sangat terbatas maka dukungan dan peran serta dari dunia usaha juga sangat dibutuhkan. Salah satu peran serta yang digali potensinya adalah peran serta perusahaan sebagai Tanggungjawab Sosial Perusahaan atau Corporate Social Responsibility (CSR) yang mengarah pada pengembangan masyarakat lokal sekitar corporat itu berdiri.

Pembangunan yang dilaksanakan untuk meningkatkan kesejahteraan masyarakat bukan hanya merupakan tanggung jawab pemerintah semata namun juga merupakan tanggung jawab sektor swasta dan masyarakat. Dengan mempertimbangkan kemampuan keuangan daerah yang terbatas, maka dibutuhkan peran aktif utamanya dari sektor swasta yang terdiri dari BUMN (Badan Usaha Milik Negara), BUMD (Badan Usaha Milik Daerah) dan BUMS (Badan Usaha Milik Swasta /Swasta murni). Salah satu wujud kepedulian dan keikutsertaan sektor swasta (dunia usaha) dalam pembangunan yaitu melalui pelaksanaan Tanggungjawab Sosial Perusahaan atau Corporate Social Responsibility (CSR).

$\begin{array}{ccc}\text { Pemerintah } & \text { Daerah } & \text { Kabupaten } \\ \text { Trenggalek melalui } & \text { Badan Perencanaan }\end{array}$
Pembangunan Daerah (Bappeda) pada Bidang Perencanaan Perekonomian sejak tahun 2013 telah melaksanakan kegiatan Fasilitasi Pelaksanaan Program CSR/PKBL BUMN/BUMD/Swasta di Kabupaten Trenggalek.

Bentuk kegiatan yang dilaksanakan yaitu koordinasi dan fasilitasi dengan BUMN/BUMD/Perusahaan Swasta dalam mengusulkan maupun menyalurkan CSRnya. Namun dalam perjalanannya ternyata masih banyak perusahaan yang kurang paham/ peduli dengan Program CSR. Dengan berlatar belakang sebagaimana yang telah diuraikan di atas, maka disusunlah penelitian ini yang sangat diperlukan untuk mengetahui tentang Peran Pemerintah dalamPengelolaan Program CSR di Kabupaten Trenggalek.

\section{B. LANDASAN TEORITIS}

\subsection{Teori Implementasi Kebijakan}

Ripley dan Franklin (dalam Winarno, 2014: 148) menyatakan bahwa implementasi adalah apa yang terjadi setelah undang-undang ditetapkan yang memberikan otoritas program, kebijakan, keuntungan (benefit), atau suatu jenis keluaran yang nyata (tangible output). Implementasi mencakup tindakan-tindakan oleh sebagai aktor, khususnya para birokrat yang dimaksudkan untuk membuat program berjalan. Grindle (dalam Winarno, 2014: 149) memberikan pandangannya tentang implementasi dengan mengatakan bahwa secara umum, tugas implementasi adalah membentuk suatu kaitan (linkage) yang memudahkan tujuan-tujuan kebijakan bisa direalisasikan sebagai dampak dari suatu kegiatan pemerintah.

James E. Anderson menyatakan bahwa Public policies are those policies developed by governmental bodies and official (kebijakan negara adalah kebijaksanaan-kebijaksanaan yang dikembangkan oleh badan dan pejabat-pejabat pemerintah). Menurut Anderson implikasi dari kebijakan negara tersebut adalah :

1. Bahwa kebijakan negara itu selalu punya tujuan tertentu atau merupakan tindakan yang berorientasi pada tujuan.

2. Bahwa kebijakan itu berisi tindakan atau pola-pola tindakan pejabat-pejabat pemerintah.

3. Bahwa kebijakan itu adalah merupakan apa yang benar-benar dilakukan oleh pemerintah.

4. Bahwa kebijakan negara itu bersifat positif dalam arti merupakan beberapa tindakan pemerintah mengenai masalah tertentu atau bersifat negatif dalam arti merupakan keputusan pejabat pemerintah dalam melakukan sesuatu.

Kebijaksanaan menurut James E.Anderson (Solichin, 2003: 2), adalah sebagai perilaku dari sejumlah aktor (pejabat, kelompok, instansi pemerintah) atau serangkaian aktor dalam sustu bidang kegiatan tertentu, pemahaman ini terkait dengan Carl Friedrich (Budi, 2002: 16), yang menyatakan bahwa kebijaksanaan sebagai suatu arah tindakan yang diusulkan oleh seseorang, kelompok atau pemerintah dalam suatu lingkungan tertentu, yang memberikan hambatan-hambatan dan kesempatankesempatan terhadap kebijakan yang diusulkan untuk menggunakan dan mengatasi dalam rangka mencapai suatu tujuan, atau merealisasikan suatu sasaran atau suatu maksud tertentu. Hal ini sebenarnya menyangkut suatu dimensi yang sangat luas, karena kebijakan tidak hanya dipahami sebagai tindakan yang dilakukan oleh pemerintah, tetapi juga oleh kelompok maupun oleh individu yang ada dalam suatu komunitas dalam masyarakat.

\subsection{Teori Perencanaan}

Perencanaan pembangunan daerah acap kali tidak selalu berjalan sesuai dengan yang diharapkan. Ada faktor-faktor penghambat dan faktor pendukung keberhasilan pada suatu kegiatan perencanaan pembangunan daerah, sebagaimana diungkapkan oleh Riyadi dan Bratakusumah (2004, h.15-38) meliputi : 
1. Faktor lingkungan, baik eksternal maupun internal yang dapat mencakup bidang sosial, budaya, ekonomi dan politik.

2. Faktor sumber daya perencana, sebagai motor penggerak perencanaan, sumber daya manusia menjadi sangat penting bahkan menjadi kunci berhasil tidaknya proses perencanaan pembangunan.

3. Faktor sistem yang digunakan, aturanaturan atau kebijakan-kebijakan yang digunakan oleh suatu daerah/wilayah tertentu sebagai dasar/landasan pelaksanaan perencanaan pembangunan.

4. Faktor perkembangan dan ilmu teknologi menjadi faktor penting dan berperan sangat besar bagi upaya pencapaian pembangunan.

5. Faktor pendanaan, merupakan faktor yang sudah given artinya harus ada sebelum melakukan suatu kegiatan atau aktivitas.

3. Pengertian dan Teori Peran

Peran adalah kelengkapan dari hubunganhubungan berdasarkan peran yang dimiliki oleh orang karena menduduki status-status sosial khusus. Selanjutnya dikatakan bahwa di dalam peranan terdapat dua macam harapan, yaitu: pertama, harapan-harapan dari masyarakat terhadap pemegang peran atau kewajibankewajiban dari pemegang peran, dan kedua harapan-harapan yang dimiliki oleh pemegang peran terhadap masyarakat atau terhadap orangorang yang berhubungan dengannya dalam menjalankan peranannya atau kewajibankewajibannya.

Peran menurut Soekanto (2009:212-213) adalah proses dinamis kedudukan (status). Apabila seseorang melaksanakan hak dan kewajibannya sesuai dengan kedudukannya, dia menjalankan suatu peranan. Perbedaan antara kedudukan dengan peranan adalah untuk kepentingan ilmu pengetahuan. Keduanya tidak dapat dipisah-pisahkan karena yang satu tergantung pada yang lain dan sebaliknya.

Sedangkan menurut Merton (dalam Raho 2007 : 67) mengatakan bahwa peranan didefinisikan sebagai pola tingkah laku yang diharapkan masyarakat dari orang yang menduduki status tertentu. Sejumlah peran disebut sebagai perangkat peran (role-set). Dengan demikian perangkat peran adalah kelengkapan dari hubungan-hubungan berdasarkan peran yang dimiliki oleh orang karena menduduki status-status sosial khusus.

Peran serta dapat pula dikenali dari keterlibatan, bentuk kontribusi, organisasi kerja, penetapan tujuan, dan peran. Parwoto (dalam Soehendy, 1997 : 28) mengemukakan bahwa peran serta mempunyai ciri-ciri :
1. Keterlibatan dalam keputusan : Mengambil dan menjalankan keputusan;

2. Bentuk kontribusi : seperti gagasan, tenaga, materi dan lain-lain;

3. Organisasi kerja : bersama setra (berbagi peran);

4. Penetapan tujuan : ditetapkan kelompok bersama pihak lain;

5. Peran masyarakat : sebagai subyek

\subsection{Teori Pemerintahan}

Pemerintahan dalam konteks penyelenggaraan negara menunjukkan adanya badan pemerintahan (institusional) kewenangan pemerintah (authority) cara memerintah (methods), wilayah pemerintahan (state, local, district, rural dan urban) dan sistem pemerintahan dalam menjalankan fungsi pemerintahannya. Pemerintahan tidak dapat dilepaskan dengan keberadaan pemerintah untuk memerintah yang merupakan keharusan untuk melaksanakan sesuatu sesuai dengan tujuan pemerintahan.

Suryaningrat (1990:10) menjelaskan bahwa unsur yang menjadi ciri khas mendasar memerintah atau perintah adalah: 1) adanya keharusan yang menunjukkan kewajiban apa yang diperintahkan; 2) adanya dua pihak, yaitu yang memberi perintah dan menerima perintah; 3) adanya hubungan fungsional antara yang memberi dan menerima perintah; 4) adanya wewenang atau kekuasaan untuk memberi perintah. Sedangkan Rasyid (1995) mengatakan bahwa pemerintahan mengandung makna mengatur, mengurus, dan memerintah dalam menyelenggarakan urusan pemerintahan bagi kepentingan rakyat.

Pemerintahan pada prinsipnya mengandung makna penyelenggaraan urusan pemerintahan. Penyelenggaraan urusan pemerintahan dapat bersumber pada pemerintahan demokratis, pemerintahan otoriter, pemerintahan sentralistis dan pemerintahan desentralistis, pemerintahan diktator, pemerintahan monarkhi dan lain sebagainya. Pemerintahan secara filosofis mengandung unsur yang berkaitan erat dengan badan publik (pemerintah) yang sah secara konstitusional; kewenangan untuk melaksanakan pemerintahan; cara dan sistem pemerintahan dan fungsi pemerintahan yang sesuai dengan kewenangan urusan pemerintahan serta dalam lingkup wilayah pemerintahan.

Ndaha (2007:127) mengemukakan bahwa pemerintahan adalah hasil dan proses "memerintah". Pemerintahan (governance) terdapat dimana-mana berlangsung pada suatu waktu di dalam setiap masyarakat. Di dalam 
masyarakat negara, pelaku yang terlibat dalam proses itu dua pihak yaitu pemerintah (government) dan yang diperintah pada masa dan tempat tertentu". Prinsip penyelenggaraan fungsi dan urusan pemerintahan yang dilakukan pemerintah (badan publik) berdimensi pengaturan berdasarkan peraturan (rulling) melalui kebijakan; pengurusan atau penataan dalam rangka (governing) dengan pengarahan, pembinaan, pemberdayaan dan fasilitasi; melaksanakan pelayanan masyarakat (serving) dalam rangka kepentingan dan kebutuhan masyarakat. Dalam penyelenggaraan fungsi dan urusan pemerintahan dengan berbagai dimensi, ruang dan waktu akan yang dilakukan oleh pemerintah melalui kebijakan dan pelayanan publik terhadap rakyat atau masyarakatnya senantiasa mengalami perubahan atau pembaharuan pemerintahan (reform governance) dengan pendekatan paradigma baru pemerintahan (new paradigms for governance) (Tjahya, 2010).

Kewenangan pemerintahan berkaitan erat dengan segala sesuatu yang melekat pada badan publik untuk melaksanakan tugas dan kewajibannya dalam mewujudkan berbagai urusan pemerintahan untuk mewujudkan keamanan, ketertiban, ketentraman, keteraturan dan kesejahteraan masyarakat. Kewenangan pemerintahan berdimensi secara esensi atau mendasar berkenaan dengan tanggungjawab, distribusi, delegasi dan lain sebagainya dalam penyelenggaraan pemerintahan bagi kepentingan masyarakat.

Setiap kewenangan pemerintahan dalam badan publik melekat tanggungjawab dalam penyelenggaraan urusan pemerintahan (authority and responcibility). Kewenangan sebagai deripasi dari hak dan tanggung jawab yang mencerminkan kewajiban untuk melaksnakan dan dilaksanakan secara institusional, manajerial dan profesional (individual). Keduanya antara kewenangan dan tanggungjawab harus dilakukan secara seimbang dan saling penguatan guna menumbuhkan satu kesatuan dalam mewujudkan kelancaran penyelenggaraan urusan pemerintahan yang baik atas dasar kualifikasi, kompetensi dan profesionalisasi.

\subsection{Teori Corporate Sosial Responsibility (CSR)}

Ide tentang tanggung jawab sosial perusahaan berkembang setiap dekade (Carroll, 1999). Namun sampai saat ini belum ada kesepakatan dalam pendefinisian CSR itu sendiri. Hal tersebut dinyatakan oleh Dahlsrud (2006) yang mencatat adasebanyak 37 definisi CSR di dunia. Hal ini mengindikasikan bahwa CSR mendapat perhatian serius sebagai tema antar para pemangku kepentingan. Banyaknya diskusi tentang isu CSR juga sangat berhubungan dengan prinsip-prinsip tata kelola perusahaan yang baik (good corporategovernance) dimana perusahaan tidak hanya memberikan perhatian kepada pemilik saham (shareholder) semata akan tetapi juga perhatian terhadap kepentingan stakeholder berdasarkan peraturan yang berlaku dan bisnis yang berkelanjutan (OECD, 2004).

Steurer (2009) memberikan beberapa alasan kenapa pemerintah memiliki kepentingan di dalam isu CSR. Pertama hal tersebut sejalan dengan konsep pembangunan berkelanjutan (sustainable development). Motivasi pertama ini berkaitan dengan politik luar negeri seperti program pengembangan sumber daya manusia (human development program). Alasan kedua adalah, kebijakan CSR dianggap sebagai pelengkap yang menarik dalam peraturan yang lain misal di Indonesia dalam undang-undang Perseroan Terbatas, dalam hal ini pemerintah dapat menunjukkan kepedulianya pada isu sosial dan lingkungan meskipun peraturan tentang tanggungjawab sosial perusahaan ini hanya mendapatkan porsi yang sangat sedikit didalam undang-undang tersebut. Ketiga adalah, pelaksanaan CSR masih sebatas pada asas sukarela (voluntary basis) sehingga pemerintah perlu memberikan penekanan agar pelaksanaan CSR lebih mendapat fokus perhatian dari perusahaan. Alasan keempat adalah, banyak pendekatan dalam pelaksanaan CSR menggunakan konsep partnership program (program kemitraan) sehingga akan membuka potensi keterlibatan masyarakat secara luas dalam pembangunan berkelanjutan. Hal ini sangat berkaitan dengan pengelolaan hubungan dan peran dengan pemangku kepentingan secara luas misalnya bisnis, pemerintah dan masyarakat sipil.

\section{METODE PENELITIAN}

$\begin{array}{crr}\text { Sebagai penelitian yang hendak } \\ \text { mendeskripsikan, } & \text { menganalisis }\end{array}$ menginterpretasikan realitas sosial di bidang perencanaan, jenis penelitian ini adalah penelitian kualitatif. Penelitian kualitatif dengan pendekatan fenomenologi merupakan upaya memahami arti peristiwa dan kausalitasnya terhadap aktor pelaku dalam situasi tertentu (Moleong, $2002 \mathrm{~h}$. 9). Moleong mengutip Bogdan dan Taylor (1975) menambahkan bahwa penelitian kualitatif merupakan penelitian yang menghasilkan data deskriptif berupa kata-kata tertulis atau lisan dari orang-orang yang diamati serta data-data tambahan lain dari berbagai sumber (Moleong, 2002 h. 3).

Analisis data dilakukan terhadap data lapang yang telah diperoleh. Analisis data dilakukan untuk menginterpretasikan fenomena 
yang diteliti berdasarkan data lapang yang diperoleh. Teknik analisis data dalam penelitian ini menggunakan metode menurut Miles, Huberman dan Saldana di dalam analisis data kualitatif terdapat tiga alur kegiatan yang terjadi secara bersamaan. Aktivitas dalam analisis data yaitu: Data Condensation, Data Display, dan ConclusionDrawing/Verifications.

1. Kondensasi Data (Data Condensation)

2. Penyajian Data (Data Display)

3. Penarikan Kesimpulan (Conclusions Drawing)

\section{PEMBAHASAN}

1. Regulasi/ peraturan daerah yang mengatur pelaksanaan dan pengelolaan program CSR.

Keberadaan Regulasi/ Peraturan Daerah tentang pelaksanaan suatu program maupun kebijakan pemerintah adalah sangat penting termasuk dalam pelaksanaan program CSR.

Peraturan Daerah sangat dibutuhkan karena selain mengacu pada Undang-Undang, Peraturan Daerah Jawa Timur maupun Peraturan Gubernur Jawa Timur maka untuk menjawab dan mengakomodir muatan lokal yang sangat penting tentunya dan mengingat tidak semua pembangunan dapat di biayai dari APBD semata. Oleh karena itu dibutuhkan bantuan pembiayaan yang lain selain dari APBN dan sumber pendanaan pusat lainnya juga dari Dunia Usaha. Aturan secara umum mengenai pengelolaan program CSR tersebut harus dituangkan dalam Peraturan Daerah yang dapat dijadikan acuan di Kabupaten Trenggalek dalam pelaksanaan Program CSR. Peraturan Daerah tentang CSR harus ada karena bermanfaat bagi pemerintah selaku pemangku kepentingan untuk mengontrol penerapan CSR perusahaan agar mampu memberikan manfaat bagi masyarakat setempat, berjalan berkelanjutan, dan sesuai konsep pemberdayaan masyarakat.

Provinsi Jawa Timur, telah membentuk Peraturan Daerah Nomor 4 Tahun 2011 yang mengatur tentang Tanggungjawab Sosial Perusahaan/ CSR. Pemerintah Kabupaten/ Kota bisa menggunakan Peraturan Daerah yang sudah ada di Provinsi sebagai landasan hukum. Peraturan Daerah Provinsi Jawa Timur Nomor 4 Tahun 2016 Tentang Tanggungjawab Sosial Perusahaan sangat penting karena dapat memberikan kepastian dan perlindungan hukum atas pelaksanaan CSR di Kabupaten Trenggalek. Selain itu dengan Peraturan Daerah dapat memberikan arahan kepada semua perusahaan dan semua pemangku kepentingan dalam pelaksanaan dan pengelolaan program CSR. Hal ini sejalan dengan Priyambodo, 2014 bahwa pemerintah baik pusat maupun daerah menyediakan perangkat peraturannya sebagai regulator dalam hubungan antara masyarakat, swasta dan pemerintah.

Hasil penelitian Windarti (2004) menunjukkan bahwa tanggungjawab sosial perusahaan dalam pemberdayaan ekonomi masyarakat ini belum diatur secara jelas dalam hirarki perundang-undangan yang berlaku di Indonesia, tetapi diatur secara teknis dalam keputusan Menteri dan Surat Edaran Menteri. Dalam Keputusan Menteri BUMN Nomor : Kep236/MBU/2004 tentang Program Kemitraan BUMN dengan Usaha Kecil dan Program Bina Lingkungan, mengatur bahwa BUMN wajib menyisihkan satu persen dari laba perusahaan untuk Program Kemitraan yang dilakukan oleh satuan kerja Pengembangan Usaha Kecil dan Koperasi (PUKK), dan Program Bina Lingkungan yang dilaksanakan oleh satuan kerja community development (comdev).

\section{Pengelolaan Program CSR oleh Pemerintah Kabupaten Trenggalek}

Pelaksanaan program CSR oleh perusahaan agar tepat sasaran dan sesuai dengan keinginan dan tujuan untuk pembangunan yang menyejahterakan masyarakat maka Pemerintah Kabupaten Trenggalek memfasilitasi dalam pelaksanaanya.

Untuk pelaksanaan program CSR dari perusahaan, yang ada di Kabupaten Trenggalek, Pemerintah Daerah telah memfasilitasi melalui kegiatan yang ada di Badan Perencanaan Pembangunan Daerah.Pemerintah Daerah telah berusaha menghimpun bantuan-bantuan yang berasal dari program CSR Perusahaan agar dapat dimanfaatkan oleh masyarakat.

Dalam pelaksanan Program CSR di Provinsi Jawa Timur yang berpedoman pada Peraturan Daerah Provinsi Jawa Timur Nomor 4 Tahun 2011 Tentang Tanggungjawab Sosial Perusahaan yang lebih lanjut mengenai petunjuk pelaksanaannya diatur dalam Peraturan Gubernur Jawa Timur Nomor 52 Tahun 2012 mengamanatkan Bappeda untuk menginisiasi pembentukan Tim Fasilitasi Pengelolaan Program CSR dan sekertariat tetap. Sekretariat tetap kemudian akan melaksanakan tugas tugas tekait pelaksanaan Tanggungjawab Sosial Perusahaan di Kabupaten Trenggalek.

Tim Fasilitasi Pengelolaan Program CSR yang merupakan Tim yang dibentuk dengan Surat Keputusan Bupati mempunyai tugas antara lain mengkoordinir dan mensinergikan Program CSR BUMN/BUMD/Swasta yang ada di Kabupaten Trenggalek agar dapat bersinergi dengan program Pemerintah Daerah. Badan 
Perencanaan Pembangunan Daerah merupakan sekretariat dari Tim Fasilitasi Pengelolaan Program CSR oleh karena untuk lebih memaksimalkan Perencanaan Pembangunan dan agar dapat bersinergi dengan Program CSR Perusahaan

\section{Permasalahan pengelolaan program CSR di} Kabupaten Trenggalek

Dalam pelaksanaan pengelolaan program CSR yang telah dilakukan oleh Pemerintah Kabupaten Trenggalek tentu saja tidak terlepas dari berbagai masalah.

Dalam pelaksanaan fasilitasi yang dilaksanakan oleh Sekretariat CSR di Bappeda masih kurang efektif yang disebabkan kurangnya komunikasi dengan Perusahaan-perusahaan. Masih banyak perusahaan yang tidak bersedia hadir pada saat diundang untuk membicarakan Program CSR sehingga menyulitkan Pemerintah dalam berkomunikasi dengan perusahaan. Pada saat Perusahaan melaksanakan Program CSR langsung kepada masyarakat tanpa ada pemberitahuan kepada Pemerintah Daerah sehingga kesulitan dalam mendata apa saja program CSR yang sudah dilaksanakan oleh Perusahaan.

Masalah dari pelaksanaan pengelolaan program CSR yaitu koordinasi dan sosialisasi selama ini dengan perusahaan maupun SKPD belum optimal.

Terdapat beberapa permasalahan dan agenda besar yang harus segera dilaksanakan oleh Tim Fasilitasi Pengelolaan Program CSR yaitu :

a. Melaksanakan Sosialisasi Peraturan Daertah Kabupaten Trenggalek Nomor 3 Tahun 2016 tentang Tanggungjawab Sosial Perusahaan. Sosialisasi dilakukan kepada seluruh SKPD dan perusahaan yang ada di Kabupaten Trenggalek;

b. Pembentukan Forum CSR yang merupakan wadah bagi perusahaan-perusahaan yang ada di Kabupaten Trenggalek untuk mendiskusikan berbagai topik program CSR/ TSP yang memungkinkan anggota tersebut berbagi informasi dan program kegiatan yang selaras dengan program prioritas Pemerintah Kabupaten Trenggalek.

4. Peran Pemerintah Kabupaten Trenggalek dalam pelaksanaan pengelolaan Program CSR

Dalam pengelolaan program CSR

Pemerintah Kabupaten Trenggalek memegang peran penting dalam pelaksanaannya.

Pemerintah Kabupaten Trenggalek berperan sebagai fasilitator dan tempat dalam hal ini sekertariat untuk menghubungkan program CSR Perusahaan dengan Program Pemerintah Daerah. Peran Pemerintah sangat strategis karena yang lebih banyak mengetahui tentang pelaksanaan pembangunan, kebutuhan masyarakat dan pembiayaan pembangunan sehingga dapat merencanakan program-program CSR agar lebih terarah. Pemerintah harus meningkatkan koordinasi dengan Perusahaan dalam rangka pelaksanaan program CSR dan komunikasi yang lebih terbuka dengan perusahaan menjadi hal yang sangat penting.(Wawancara tanggal 1 September 2016).

Dalam pelaksanaan kegiatan CSR dengan pelaksanaan program/ kegiatan pembangunan, terutama yang terkait dengan percepatan pembangunan daerah, ada 4 (empat) fungsi yang harus diperankan pemerintah daerah, yaitu:

a) Menyediakan data dan informasi

b) Memberikan konsultasi perencanaan

c) Melakukan supervisi pelaksanaan

d) Melakukan monitoring dan evaluasi

Peran dari Pemerintah Daerah sebagai Tim Pengelolan CSR sangat strategis karena dapat mensuport kinerja pembangunan daerah dengan menambah sumber pembiayaan diluar APBD. Hal ini harus terus ditingkatkan dengan harapan semakin banyak perusahaan yang dapat membantu Pemerintah Daerah dalam pembiayaan pembangunan.

\section{Manfaat pelaksanaan pengelolaan Program CSR di Kabupaten Trenggalek}

Pelaksanaan pengelolaan Program CSR di Kabupaten Trenggalek mempunyai tujuan agar dapat dirasakan manfaatnya oleh masyarakat. Program CSR dari Perusahaan sangat bermanfaat untuk membantu Pemerintah dalam pembangunan karena tidak mungkin semua pembiayaan pembangunan daerah dapat dibiayai dari Anggaran Pendapatan dan Belanja Daerah. Manfaat dari program CSR Perusahaan tentunya sangat dirasakan terutama bagi masyarakat yang mendapatkan program tersebut seperti pembagian sembako dan pasar murah yang pernah dilaksanakan beberapa kali oleh beberapa Perusahaan yang ada di Kabupaten Trenggalek.

Program CSR merupakan salah satu sumber pembiayaan yang dapat dimanfaatkan oleh Pemerintah Daerah dengan mensinergikan program pembangunan untuk kesejahteraan masyarakat. Program CSR bermanfaat bagi lingkungan sekitar perusahaan karena dapat mendukung kegiatan-kegiatan yang dapat memberdayakan masyarakat sekitar perusahaan. Dengan adanya program CSR semoga dapat juga membantu mengurangi kemiskinan dan pengangguran di Kab. Trenggalek".

Di dalam Peraturan Daerah Provinsi Jawa Timur Nomor 4 Tahun 2011 Tentang Tanggungjawab Sosial Perusahaan diamanatkan bahwa dalam rangka mewujudkan kesejahteraan 
dan kemakmuran masyarakat serta kelestarian fungsi lingkungan hidup yang merupakan bagian integral dalam penyelenggaraan Pemerintahan Daerah dapat terlaksana dengan baik bila terjalin hubungan sinergis antara Pemerintah Daerah dengan para pelaku dunia usaha dan masyarakat.

Program CSR ternyata sangat dirasakan manfaatnya oleh masyarakat dan sebisa mungkin pemanfaatannya dapat dimanfaatkan untuk halhal yang mudah dinikmati dan dilaksanakan.

Dari keseluruhan pelaksanaan program CSR yang telah dilaksanakan di kabupaten Trenggalek dan di fasilitasi oelh Tim Fasilitasi Pengelolaan Program CSR terdapat pada tabel realisasi program CSR mulai Tahun 2013 sampai dengan tahun 2016.

Apabila masyarakat di sekitar perusahaan terkesan karena perusahaan yang selalu peduli dengan program CSR nya maka hal ini akan membawa keuntungan jangka pangjang bagi perusahaan tersebut sebagaimana menurut Direktur CSR Universitas Trisakti Maria R Nindita Radyanti, CSR adalah investasi perusahaan dalam jangka panjang dan merupakan strategis sesuai bisnis intinya. "Bukan hanya sekedar alat public relation maupun marketing, tapi sebagai rangkaian manajemen produksi, sumberdaya hingga pemasaran," katanya. Prinsipnya kata dia, dalam mengambil keputusan perusahaan bertujuan mencapai kesejahteraan internal dulu baru kemudian menyebarkan kesejahteraan di luar. "Di sini, CSR merupakan kegiatan sukarela (voluntary) kepada masyarakat di luar perusahaan," tutur Maria.

\section{E. KESIMPULAN DAN REKOMENDASI \\ 5.1. Kesimpulan}

1) Peran dari Pemerintah Daerah Kabupaten Trenggalek dalam Fasilitasi Pengelolaan Program CSR yaitu :

a. penyedia data dan informasi dalam rangka harmonisasi Program CSR Perusahaan dengan Program Pembangunan Daerah.

b. Perencana pembangunan Pemerintah Daerah memiliki pengetahuan yang lebih baik oleh karena itu diperlukan oleh pihak swasta dalam perencanaan kegiatan CSRnya.

c. Pelaksana monitoring dan evaluasi Program CSR. Hal ini dilakukan oleh Pemerintah Daerah untuk melihat dan menilai terhadap kegiatan CSR yang dilaksanakan baik oleh perusahaan yang bersangkutan maupun yang dikerjakan pihak ketiga.
2) Dari keseluruhan pelaksanaan program CSR yang telah dilaksanakan di Kabupaten Trenggalek ternyata memberikan manfaat bagi :

a. Pembangunan dengan tersedianya sarana dan prasarana umum yang sangat membantu untuk pelayanan kebutuhan masyarakat dan kenyamanan masyarakat.

b. Masyarakat dengan berbagai bantuan yang dapat meringankan kebutuhan hidupnya.

\subsection{Rekomendasi}

1) Untuk Pemerintah Daerah Kabupaten Trenggalek yaitu harus selalu meningkatkan koordinasi, sinkronisasi dan komunikasi untuk mensinergikan program dan kegiatan guna mendukung program / prioritas pembangunan di Kabupaten Trenggalek dalam rangka peningkatan kesejahteraan rakyat secara lebih merata dan berkelanjutan.

2) Untuk perusahaan-perusahaan yaitu Program CSR yang selalu di identikan dengan perusahaan-perusahaan besar, tidak benar karena tanggungjawab ini melekat pada semua kegiatan usaha tanpa memandang ukurannya. Bahkan, usaha kecil dan menengah sekalipun memikul tanggungjawab sosial tersebut.

3) Perlu dilakukan penelitian lebih lanjut mengenai keberhasilan atau kesuksesan dari program CSR yang dapat dijadikan motivasi bagi Perusahaan- perusahaan untuk lebih peduli pada lingkungan dan masyarakat sekitarnya.

\section{F. REFERENSI}

Abe, Alexander, 2001. Perencanaan Daerah : Memperkuat Prakarsa RakyatDalam Otonomi Daerah. Yogyakarta: lapera Pustaka Utama.

Anderson, James E., Publik Policy Making, New York, Holt RinehartandWinston, 2n dec, 1979.

Carrol, A. B., and Shabana, K. M, 2010,The Business Case for CorporateSocial Responsibility: A Review of Concepts, Research and Practice, International Journal of Management Review.

Darwin, A. (2009). Tailor CSRCommunication.http://www.thejakart apost .com/news/2009/08/05/tailoringcsrcommunica

Friedman, M., 1970, The social responsibility of business is to increase its profits, The New York Times Magazine, September 13, available

athttp://www.colorado.edu/studentgroup 
s/libertarians/issues/friedmansocrespbusiness.html

Kartasasmita, Ginandjar, 1997. Administrasi Pembangunan: Perkembangan Pemikiran dan Praktiknya di Indonesia, Jakarta: LP3ES

Miles, Matthew B dan A. Michael Huberman. 1992. Analisis Data Kualitatif: Buku Sumber tentang Metode-Metode Baru. Diterjemahkan oleh Tjejep Rohendi Rohidi. UI Press: Jakarta.

Moleong, Lexy J., 2002, Metodologi Penelitian Kualitatif. Cetakan keenambelas.PT. Remaja Rosdakarya: Bandung.

Riyadi dan Deddy Supriady Bratakusumah. 2004. Perencanaan Pembangunan Daerah: Strategi Menggali Potensi Dalam Mewujudkan Otonomi Daerah. PT. Gramedia Pustaka Utama: Jakarta.

Steurer, R. (2009). The role of governments in corporate social responsibility: characterising public policies on CSR in Europe. Springer Science+Business Media,LLC.

Sweeney, L, Coughlan, J. (2008). Do different industries report Corporate Social Responsibility differently? An investigation through the lens of stakeholder theory.Journal of Marketing Communications, 14(2), 113 - 124.

Tschopp, 2005, Corporate social responsibility: A comparison between the United States and the European Union, Corporate Social-
Responsibility and Environmental Management, Vol. 12 No. 1, 55-59.

Wibisono, Yusuf. Membedah Konsep dan Aplikasi CSR. Gresik: Fascho Publishing,2007.

Winarno, Budi.,Teori dan Proses Kebijakan Publik, Yogyakarta, Media Pressindo, 2004.

Kebijakan Publik Dalam Perspektif Teori Siklus Kebijakanhttp://fia.unira.ac.id/ wpcontent/uploads/2012/06/PublikaTahun-IINomor-2-Juli-

2011.pdf

Juliartha, Edward. 2009. Model Implementasi Kebijakan Publik. Jakarta: Trio Rimba Persada 